\title{
PERNIKAHAN DINI DAN PERCERAIAN DI INDONESIA
}

\author{
Fathur Rahman Alfa, MA \\ Dosen Universitas Islam Malang \\ e-mail: fathur.rahman.alfa@unisma.ac.id
}

Diterima: 16 - 05 - 2019 | Direvisi: 10 - 06 - 2019 | Disetujui: 10 - 06 - 2019

(C) 2019 Program Studi Ahwal Syakhshiyyah Fakultas Agama Islam Universitas Islam Malang

\begin{abstract}
Abstrak
Permasalahan perceraian menjadi persoalan penting. Banyak keluarga yang terkena permasalahan cerai. Akibat yang tidak dikehendaki muncul dari kasus perceraian. Mulai dari kekerasan kecil hingga kekerasan berat yang mengakibatkan seseorang terkena hokum penjara. Permusuhan dan pertikaian antar keluarga. Anak anak yang terlantar karena perceraian. Dalam rumah tangga permasalahan selalu ada dan apabila tidak bias diselesaikan akan mengekibatkan terjadinya perceraian. Penelitian menggunakan pendekatan ranah kualitatif. Penelitian sifatnya lebih ke arah metode kajian atas gagasan konseptual dengan data-data yang dikumpulkan dan yang akan dianalisis bertumpu pada ketersediaan sumber data di perpustakaan (Library Research). Sedang untuk teknik nalisis data yang digunkan dalam kajian ini adalah teknik Analisis isi (content analysis). Perkawinan hal yang sangat sakral dan jika dihindari adanya perceraian untuk menjaga keutuhan rumah tangga dengan cara melihat aspek-aspek yangmendukung baik itu lahir batin, biologis dan psikologis seseorang apakah sudah dewasa atau mapan untuk melangsungkan pernikahan. Sedangkan beberapa faktor yang mendorong terjadinya pernikahan muda di Indonesia adalah pertama faktor individu pelaku yang disebabkan oleh rendahnya tingkat pendidikan dan bimbingan masalah perkawinan, ditambah lagi maraknya gerakan menikah muda dari sejumlah aktivis keagamaan yang menggalakkan pernikahan muda tanpa memberi edukasi yang seharusnya untuk para pelaku pernikahan dini. Faktor kedua yaitu faktor eksternal seperti perjodohan, orang tua, lingkungan (adat istiadat) dan ekonomi.
\end{abstract}

Kata kunci: Pernikahan Dini, Perceraian,

This work is licensed under Creative Commons Attribution Non Commercial 4.0 International License Available online on: http://riset.unisma.ac.id/index.php/fai/index 


\section{A. Pendahuluan}

Perceraian menjadi permasalahan perlu diperhatikan di tingkat daerah maupun tingkat nasional. Banyak keluarga yang terkena permasalahan cerai. Akibat yang tidak dikehendaki muncul dari kasus perceraian. Mulai dari kekerasan kecil hingga kekerasan berat yang mengakibatkan seseorang terkena hokum penjara. Permusuhan dan pertikaian antar keluarga. Anak anak yang terlantar karena perceraian. Dalam rumah tangga permasalahan selalu ada dan apabila tidak bias diselesaikan akan mengekibatkan terjadinya perceraian.

Setiap orang senantiasa mendambakan suasana lingkungan yang kondusif, penuh kedamaian, kesejukan, dan ketenangan lahir batin dalam lingkunga di mana mereka tinggal. Tetapi hal yang selalu terlupakan untuk menciptakan kondisi yang demikian adalah bagaimana menjaga dan melestarikan iklim tersebut agar tetap harmonis, walaupun sedang dihadapkan dengan berbagai cobaan kehidupan.kedamaian akan senantiasa diperoleh jika mengedepankan pemikiran yang jernih dengan tetap mempertahankan, menjaga, dan memahami hak dan kewajiban manusia sebagai makhluk sosial dalam lingkungan yang homogen.

Tidak terkecuali dalam kehidupan berumah tangga, baik suami, isteri, dan anak-anak dituntut untuk menciptakan kondisi keluarga yang sakinah, mawaddah, wa rahmah. Untuk menciptakan kondisi demikian, tidak hanya berada di pundak isteri (sebagai ibu rumah tangga) atau suami (sebagai kepala rumah tangga) semata, tetapi secara bersama-sama berkesinambungan membangun dan mempertahankan keutuhan pernikahan. Karena pernikahan dalam Islam tidak semata-mata sebagai kontrak keperdataan biasa, tetapi memiliki nilai ibadah.

Untuk menjaga kelanggengan sebuah pernikahan, setiap pasangan berkewajiban memelihara prinsip pernikahan (sakinah, mawaddah, wa rahmah), saling melengkapi dan melindungi. Maka suami, istri, maupun anka berperan penting pada terciptanya keluarga bahagia.

\section{B. Metode}

Penelitian ini adalah menggunakan pendekatan ranah kualitatif. Penelitian ini sifatnya lebih ke arah metode kajian atas gagasan konseptual dengan data-data yang dikumpulkan dan yang akan dianalisis bertumpu pada ketersediaan sumber data di perpustakaan (Library Research). Sedang untuk teknik nalisis data yang digunkan dalam kajian ini adalah teknik Analisis isi (content analysis) 
memahami inti dari keterangan, pesan atau informasi yang disajikan dalam wujud lambang atau simbol tertentu yang terdokumentasi atau dapat didokumentasikan.

\section{Hasil dan Pembahasan}

Agama Islam adalah agama yang fitrah, dan manusia diciptakan oleh Allah SWT sesuai dengan fitrahnya. Perkawinan merupakan fitrah manusia, maka dari itu Islam menganjurkannya karena menikah merupakan naluri kemanusiaan. Bila naluri ini tidak dipenuhi melalui jalan yang sah yaitu perkawinan, maka akan terdapat jalan setan yang menjerumuskan ke lembah hitam. Firman Allah SWT dalam surah Ar Ruum ayat 30 yang berarti sebagai berikut:

"Maka hadapkanlah wajahmu dengan lurus kepada agama (Allah); (tetaplah atas) fitrah Allah yang telah menciptakan manusia menurut fitrah itu. Tidak ada perubahan pada fitrah Allah. (Itulah) agama yang lurus; tetapi kebanyakan manusia tidak mengetahui". (QS. 30: 30).(terjemah Departemen Agama Indonesia)

Agama Islam memandang pernikahan sebagai sesuatu yang suci dan sakral, bertujuan ibadah kepada Allah dan mengikuti Sunnah. Dalam Undang Undang RI nomor 1 tahun 1974 tentang perkawinan bab I pasal 1, perkawinan ialah ikatan lahir batin antara seorang pria dan seorang wanita sebagai suami-isteri dengan tujuan membentuk keluarga (rumah tangga) yang bahagia dan kekal berdasarkan Ketuhanan Yang Maha Esa.

Pernikahan adalah sunnah Nabi Muhammad SAW. Perkawinan bertujuan supaya manusia mempunyai keturunan dan keluarga untuk mewujudkan kehidupan bahagia di dunia akhirat, yang diridhai Allah SWT. Hal ini telah diisyaratkan sejak zaman dahulu, dan sudah banyak dijelaskan di dalam Al Quran surah An Nuur ayat 32 yang berarti:

"Dan kawinlah orang-orang yang sendirian diantara kamu, dan orang-orang yang layak (berkawin) dari hamba-hamba sahayamu yang lelaki dan hamba-hamba sahayamu yang perempuan. Jika mereka miskin Allah akan memampukan mereka dengan karunia-Nya. Dan Allah Maha Luas (pemberian-Nya) lagi Maha mengetahui" (QS. 24: 32) (terjemah Departemen Agama Republik Indonesia)

Pernikahan usia dini masih banyak terjadi di indonesia. Dimana kebanyakan orang tua menikahkan anaknya karena alasan ekonomi, hal lainnya juga dipengaruhi alasan sosial dan budaya seperti adat orang tua harus menjodohkan JAS: Volume 1 Nomor 1, 2019 
anaknya sejak mereka masih kecil, pandangan masyarakat yang negatif yaitu dianggap perawan tua terhadap perempuan yang menikah di usia 18 tahun.

Data Survey Demografi Kesehatan Indonesia (SDKI) tahun 2007 menunjukan 22 persen perempuan menikah sebelum usia 18 tahun. Beberapa daerah di Indonesia seperti Bondowoso menunjukan angka pernikahan usia dini yang lebih tinggi yaitu 57\% dan dalam waktu 1 tahun 50 persen dari pernikahan tersebut berakhir dengan perceraian.

Berdasarkan data dari UNICEF, perempuan yang melahirkan pada usia 1419 tahun akan mengalami resiko kematian 2 kali lebih besar dibandingkan perempuan yang melahirkan pada usia diatas 20 tahun. Di tahun 2011 di Bondowoso ditemukan 192 kasus kematian bayi karena kurang gizi akibat kurangnya pengetahuan ibu.

Praktek perkawinan di bawah umur terjadi di banyak negara terutama di negara-negara sub sahara Afrika dan Asia Selatan. Data Perserikatan BangsaBangsa, Agustus 2012 menunjukan bahwa Niger dan Chad adalah dua negara dengan ranking tertinggi angka kawin di bawah umur dengan masing-masing mencapai 75 dan 72 persen dan indonesia menduduki rankng 57 dengan 22 persen angka kawin di bawah umur. Sedangkan beberapa Negara Islam seperti Iran, Tunisia , Malaysia memeliki 0\% angka kawin di bawah umur. Negara Saudi Arabia, negara tempat lahirnya Islam ternyata juga tidak tercatat adanya perkawinan di bawah umur- 0\% (patut dipertanyakan kalau agama dianggap sebagai faktor yang mempengaruhi perilaku atau kebiasaan perkawinan di bawah umur).

Pernikahan dini secara faktual memiliki banyak dampak negatif. Plan Indonesia, dalam penelitiannya menemukan bahwa pernikahan usia dini mempengaruhi secara negatif masa depan perempuan, kerena pernikahan usia dini akan membatasi gerak sang perempuan, membuat mereka tak punya kesempatan melakukan berbagai hal yang seharusnya mereka lakukan pada usia tersebut. Dari $33.5 \%$ perempuan yang menikah pada usia dini, hanya sekitar 5.6\% yang masih melanjutkan pendidikannya. Namun, apabila harus memasuki dunia kerja, mereka juga tidak siap karena minimnya pengetahuan dan pengalaman. Selain itu, pernikahan dini menempatkan perempuan pada kerentanan untuk mengalami Kekerasan Dalam Rumah Tangga. Sekitar 44\% perempuan yang menikah dini mengalami kekerasan dalam rumah tangga (KDRT) dengan frekuensi yang cukup tinggi. Sedangkan, 56\% perempuan sisanya mengalami KDRT dalam frekuensi JAS: Volume 1 Nomor 1, 2019 
rendah. Banyaknya jumlah tersebut dipicu karena tingginya pernikahan di bawah umur. Hal ini bisa terjadi, karena biasanya pelaku pernikahan dini memang belum memiliki kesiapan ekonomi maupun mental untuk berumahtangga. Sedikit badai sangat rawan menggoyahkan rumah tangga pelaku pernikahan dini.

Tujuan perkawinan seperti disebutkan itu kadang terhalang oleh keadaan yang tidak dibayangkan sebelumnya. Para ahli hokum berpendapat faktor-faktor yang mempengaruhi terjadinya perkawinan usia muda salah satunya menurut RT. Akhmad Jayadiningrat, faktor-faktor yang mendasari terjadinya perkawinan usia muda diantaranya

a. Menginginkan anggota tambahan baru dalam keluarga

b. Kurangnya pemahaman efek pernikahan terlalu muda terhadap kedua mempelai dan anak turunnya.

c. Adat yang sangat kuat dipercayai dimasyarakat yang mempunyai efek kebaikan.

d. Masalah ekonomi keluarga

e. Menghindari pergaulan bebas dikalangan anak usia muda

Sejalan dengan hal diatas, juga menjelaskan diantara faktor-faktor yang menyebabkan keretakan dan perselisihan terus-menerus pada pasangan perkawinan usia muda sehingga sampai terjadinya perceraian adalah:

a. Perkawinan pada usia muda, yang mengakibatkan kedua pasangan tersebut belum bias berfungsi secara baik sebagai suami istri.

b. Masalah ekonomi, yang menjadi faktor yang utama dalam perceraian.

c. Kurang mengetahui dan mempelajari agama, hal demikian dapatt menimbulkan kekacauan rumah tangga dimana si suami tidak tahu fungsinya dan si istrinya tidak tahu kewajibannya

d. Kepribadian yang egoistis baik salah satu maupun kedua-duanya sehingga sulittt untutk mencapai mawaddah dan rahmah yyang merupakan wujud dari keharmonisan dan keserasian dalam rumah tangga.

Yang dimaksud sebagai pernikahan di usia muda aalah pernikahan yyang dilangsungkan seorang pria dibawah 19 tahun dan perempuan berusia dibawah 16 tahun. Pernikahan ini yang biasa dikenal dengan pernikahan dini.

Undang-undang perkawinan membahas tujuan membentuk keluarga dan menghindari perceraian. Dibutuhkan alasan dan sebab yang kuat "untuk melakukan perceraian itu harus ada cukup alasan". Adapun alasan yang dimaksud, tercantum 
dalam penjelasan umum pasal 39 (2) UU No. 1 Tahun 1974 yang berbunyi sebagai berikut:

a. Sebab perzinaan, dan kelakuan buruk dari salah satu mempelai

b. Dua tahun berturut, ditinggalkan atau salah satu fihak meninggalkannya tanpa izin, atau disebabkan ketidakmampuan.

c. Hukuman penjara yang dijalani oleh salah satu fihak selama 5 tahun atau lebih

d. Berlaku kejam dan penganiayaan, kekerasan berat oleh salah satu fihak mempelai

e. Cacat fisik maupun psikis yang menjadikan sebab, kewajiban sumami istri tidak dapat terjalani

f. Tidak adanya kerukunan dalam rumah tangga karena pertikaian dan pertengkaran di kedua fihak.

g. Suami melanggar ta'lik talak

h. Berpindah agama diantara salah satu pihak sehingga kerukunan tidak dapat terwujud

Sedangkan dalam pandangan islam, memang tidak terdapat dalam al-Qur'an ayat-ayat yang menyuruh atau melarang adanya perceraian, sedangkan untuk perkawinan, ada beberapa ayat yang menganjurkan melakukannya. Meskipun cukup banyak ayat dalam al-Qur'an yang mengatur tentang talaq, tetapi isinya hanya mengatur bila talaq itu terjadi. Apabila hendak mentalak seharusnya sewaktu istri itu berada dalam keadaan yang siap untuk memasuki masa iddah, seperti dalam firman Allah dalam surat At-Thalaq ayat 1:

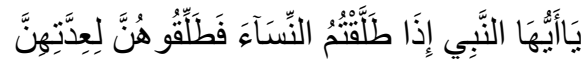
"Hai Nabi bila kamu mentalak istrimu, maka talaklah dia sewaktu masuk ke dalam iddahnya".

Demikian pula dalam bentuk melarang, seperti firman Allah dalam surat AlBaqarah ayat 232:

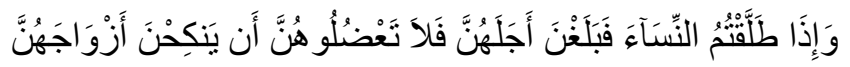

"Apabila kamu mentalak istrimu dan sampai masa iddahnya, maka janganlah kamu enggan bila dia nikah suami yang lain".

Meskipun tidak ada ayat al-Qur'an yang dengan jelas menganjurkan atau melarang talak yang dapat disimpulkan hukumnya mubah, namun talak itu termasuk perbuatan yang tidak disukai oleh Rasulullah. Hal ini menunjukkan bahwa perceraian itu hukumnya makruh. Ketidak senangan Rasulullah kepada perceraian JAS: Volume 1 Nomor 1, 2019 
itu tertuang dalam hadis riwayat Ibnu Umar. Menurut riwayat Abu Daud, Ibnu Majah. Rasulullah bersabda:

"Perbuatan halal yang paling dibenci Allah adalah talak".

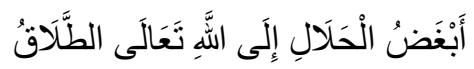

Walaupun hukum asal dari talak itu sendiri adalah makruh, namun berdasarkan keadaan tertentu dalam situasi tertentu, maka hukum talak itu dapat berubah tergantung dengan sebab dan kondisi yang ada pada keluarga tersebut. Hukum yang Nadab atau sunnah ketika kemudharatan akan timbul lebih besar dalam keluarga. Mubah atau boleh ketika terdapat manfaat dan tidak ada yang dirugikan. Wajib atau mesti bila sumpah seorang suami dilanggar dan mendatangkan mudharat bagi sitri. Haram talak saat istri dalam keadaan haid dan tidak ada alasan yang menjadi seabab talak tersebut. (Syarifuddin, 2014)

Solusi menghindari perceraian yang dapat dilakukan adalah: Mencukupi kebutuhan rumah tangga yang bersifat lahir, Rumah tangga dicukupi kebutuhan batinnya, adanya komunikasi yang saling pengertian dan memahami di kedua belah pihak. Keterbukaan dilakukan oleh kedua belah pihak terkait rumah tangganya. Menjauhi sikap diskriminasi dalam keluarga. Mampu menerima ide atau masukan dan menjauhi fanatik perbedaan ide. Menjauhi pertengkaran dalam urusan keluarga. menghindari cemburu/curiga berlebihan tanpa sebab yang pasti benar. Adanya sikap intropeksi diri yang dilakukan masing-masing pihak. Menjauhi intimidasi terhadap anggota keluarga dan tindak kekerasan. Memutus komunikasi dengan pihak penyebab perselingkuhan.

Bila kita kaji lebih jauh lagi, sebetulnya, kasus Nabi Muhammad SAW menikahi Siti A'isyah dalam usia dini tersebut adalah satu-satunya dalam sejarah perkawinan yang pernah dilaksanakannya, selebihnya adalah wanita-wanita dewasa yang berstatus janda, bahkan sebagian berusia lebih tua dari pada usia Nabi sendiri. Lebih dari itu, syari'at agama sendiri melihat perkawinan dini tidak sebagai beban yang bersifat keharusan, akan tetapi lebih merupakan pilihan.

\section{Simpulan}

Perkawinan hal yang sangat sakral dan jika dihindari adanya perceraian untuk menjaga keutuhan rumah tangga dengan cara melihat aspek-aspek yangmendukung baik itu lahir batin, biologis dan psikologis seseorang apakah sudah dewasa atau mapan untuk melangsungkan pernikahan. Sedangkan beberapa 
faktor yang mendorong terjadinya pernikahan muda di Indonesia adalah pertama faktor individu pelaku yang disebabkan oleh rendahnya tingkat pendidikan dan bimbingan masalah perkawinan, ditambah lagi maraknya gerakan menikah muda dari sejumlah aktivis keagamaan yang menggalakkan pernikahan muda tanpa memberi edukasi yang seharusnya untuk para pelaku pernikahan dini. Faktor kedua yaitu faktor eksternal seperti perjodohan, orang tua, lingkungan (adat istiadat) dan ekonomi.

Dengan demikian, melihat dampak negatif perkawinan usia anak sebagaimana direkomendasikan oleh lembaga-lembaga Internasional dan para ahli, sebaiknya kita perlu mencermati kembali universalitas agama dan elastisitas syariatnya dalam rangka mencari furmula yang paling maslahat dan selaras dengan dinamika realitas. Dan akhirnya kita mampu melahirkan generasi yang tangguh yang tidak hanya berguna bagi dirinya sendiri, tetapi juga untuk negara dan lingkungannya.

\section{DAFTAR PUSTAKA}

Sarifuddin, A. 2014. Hukum Perkawinan di Indonesia. Jakarta: Kencana 